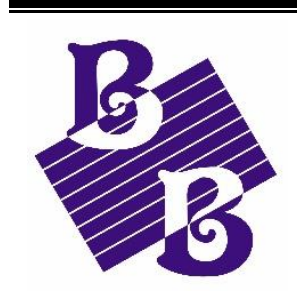

BioBacta

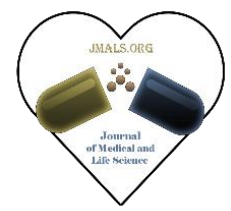

Journal of Medical and Life Science

http://imals.journals.ekb.eg/

\title{
Assessment of Serum Urea, Creatinine, and electrolytes in Patients with Prostate Cancer under Androgen Deprivation Therapy
}

\author{
Salma Mohamed Elhassan ${ }^{1}$, Yousra A.Suliman ${ }^{2}$, GadAllah Modawe ${ }^{3 *}$
}

1. Alneelain University, Faculty of Medical Labrotory Sciencs, Clinincalchemistry Department.

2. Omdurman Islamic University, Faculty of Medicine and Health Sciences, Oncology Department.

3. Omdurman Islamic University, Faculty of Medicine and Health Sciences,Biochemistry Department.

Coresponding author: gadobio77@ @otmail.com. Received Jan, 25, 2019; Accepted March,5,2019

\begin{abstract}
Background: Prostate cancer is the most common cancer in a male of the reproductive system and associated with high mortality and Androgen-deprivation therapy (ADT) is a key component of treatment for aggressive and advanced prostate cancer. Objective: The aim of this study was to assess the serum urea and creatinine beside the measure of serum electrolytes $(\mathrm{Na}$ and $\mathrm{K}$ ) in patients with prostate cancer under (ADT).Methodology: 100 Sudanese patients with prostate cancer (PCa) under (ADT) attended in Khartoum oncology hospital, Khartoum state. The study conducted in April and July 2018. The age of PCa patients ranged between ( 50 to73 years) and their mean 62.2 years. The blood samples were taken from each patient. The urea and creatinine were estimated using spectrophotometer methods and also the serum electrolytes were measured by using flame photometers methods. Results: The (mean $\pm \mathrm{SD}$ ) of serum urea, creatinine, Na and $\mathrm{K}$ were $(41.31 \pm 27.6 \mathrm{mg} / \mathrm{dl}, 1.26 \pm 0.93 \mathrm{mg} / \mathrm{dl}, 141.37 \pm 11.52 \mathrm{mg} / \mathrm{dl}, 4.38 \pm 3.89 \mathrm{mg} / \mathrm{dl}) \quad$ respectively. The concentration of serum urea, creatinine, $\mathrm{Na}$ and $\mathrm{K}$ were normal within a normal range. There was significantly $(\mathrm{P}=0.000)$ difference of serum urea among prostate cancer patients under ADT and there was a significant correlation between urea and creatinine and also between $\mathrm{Na}$ and $\mathrm{K}$. Conclusion: In this study concluded that the ADT has no effect on blood renal parameters among prostate cancer.
\end{abstract}

Key words: Prostate cancer, renal efficiency, cancer therapy, serum electrolytes.

\section{Introduction}

Prostate cancer is the second cancer leasing cause of death in elderly age associated with gene polymorphism (Cairns et al., 2001). Androgen deprivation therapy (ADT) reduces testosterone levels leading to a hypogonadal condition marked by metabolic changes, such as hyperlipidemia, (Braga et $a l ., 2006)$ increase blood glucose (Basaria,2008), and an increase in fat contents (Braga e tal.,2006). With respect to the renal system, hyperglycemia and 
dyslipidemia may disrupt glomerular function by expanding and thickening the interstitial tubular membrane (Kambnam et al., 2001).Furthermore, by lowering testosterone to castration levels, ADT may antagonize the vasodilating effects of testosterone on renal vessels (Molinari et al., 2002).while also creating an estrogen deficiency, which can negatively affect renal tubular function (Hutchens et al., 2012). Prostate cancer has associated with end-stage renal disorders and also age-related (Wada et al., 2006). The objective of this study was to assess the serum urea and creatinine beside the measure of serum electrolytes ( $\mathrm{Na}$ and $\mathrm{K}$ ) in patients with prostate cancer under (ADT) therapy.

\section{Materials and Methods}

\section{Study populations}

This is a descriptive cross-sectional, hospital-based study, was carried in Khartoum state, Khartoum oncology hospital. The study period from April to July 2018. 100 subjects known diagnosed with prostate cancer under Androgen deprivation therapy were enrolled in this study. The age of PCa patients ranged between (50 and 73years) and their mean was 62.2 years. The most common clinical signs and symptoms of these patients were loss of weight, difficulty urination, hematuria, pain in the pelvis, headache, fever, stomach pain, nausea, vomiting, and diarrhea. And the main chemotherapy of these patients in this study includes Casodex, Zoladex, ondansetron and dosetaxal.

\section{Samples and data collection}

Samples were collected using dry, plastic syringes, tourniquet used to make the veins more prominent. A $3 \mathrm{ml}$ blood sample was collected in heparin containers from each volunteer under septic conditions. The blood was centrifuged at 3000 r.p.m for 10 minutes which was stored in small aliquots and kept in a deep freezer $\left(-20 \mathrm{C}^{\circ}\right)$ until analyzed. The data were collected in patients using questionnaire form includes personal data such as age, clinical data includes (signs and type of chemotherapy) and laboratory data such as urea, creatinine, sodium, and potassium which is estimated in the laboratory. All reagents kits were obtained in the biosystem company. The urea and creatinine were estimated using spectrophotometer methods and also the serum electrolytes were measured by using flame photometers methods.

\section{Inclusion criteria}

Patients with prostate cancer under Androgen deprivation therapy.

\section{Exclusion criteria}

Patient with condition that affects plasma lipid level includes liver disease, renal diseases, malnutrition patient and diabetes mellitus.

\section{Quality controls}

The precision and accuracy of methods that used in this study were checked each time by using control material.

\section{Ethical approval}

This study approved from the committee of the department of clinical chemistry, Faculty of Medical Laboratory Sciences, Alneelain University, Khartoum, Sudan.

\section{Statistical analysis}

The data of this study were analyzed using the statistical package for social study (SPSS) software (version21). Student's t-test presented as (mean $\pm \mathrm{SD}$ ). A $P$-value of less than 0.05 was considered statistically significant.

\section{Results}

One hundred subjects known diagnosed prostate cancer under Androgen deprivation therapy were enrolled in this study. The age of PCa patients ranged between (50 and 73years). Overall, the mean age was 
$(62 \pm 5.8)$ was presented in table 1$) .100$ participants $(65 \%)$ were $\geq 60$ years old, and $35 \%$ were $\leq 60$ years old, was presented in figure1. In table 2 show the $($ mean $\pm \mathrm{SD})$ of serum urea, creatinine, $\mathrm{Na}$ and $\mathrm{K}$ were $(41.31 \pm 27.6 \mathrm{mg} / \mathrm{dl}$, $1.26 \pm 0.93 \mathrm{mg} / \mathrm{dl}$, $141.37 \pm 11.52 \mathrm{mg} / \mathrm{dl}, 4.38 \pm 3.89 \mathrm{mg} / \mathrm{dl})$ respectively.
$\mathrm{K}$ were normal within normal range. There was significantly $(\mathrm{P}=0.000)$ difference of serum urea among prostate cancer patients under androgen deprivation therapy. In table 4 , there was a significant correlation between urea and creatinine and also between $\mathrm{Na}$ and $\mathrm{K}$.

The concentration of serum urea, creatinine, $\mathrm{Na}$ and

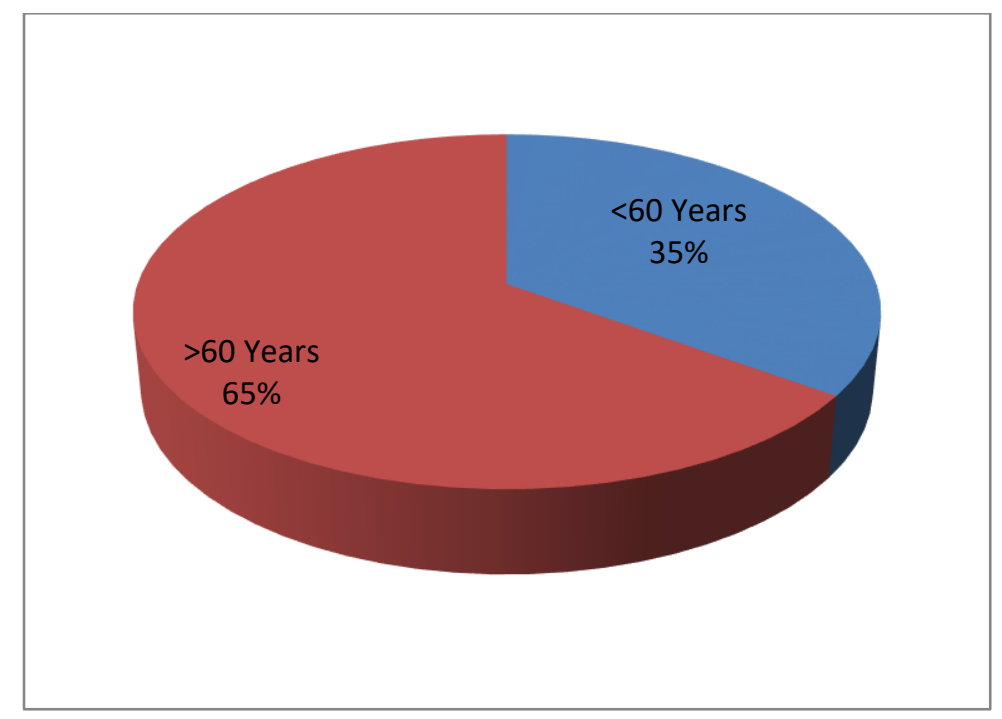

Figure 1: distribution of age in the study

Table 1: The mean of the age in the study population

\begin{tabular}{|r|r|r|r|}
\hline Variables & Minimum & Maximum & Mean \pm SD \\
\hline Age (Years) & 50.00 & 73.00 & $62.2 \pm 5.8$ \\
\hline
\end{tabular}

Table 2: The serum urea, creatinine , $\mathrm{Na}$ and $\mathrm{K}$ in the study population

\begin{tabular}{|c|c|c|c|}
\hline Parameters & Mean \pm SD & R.V & P-value \\
\hline Urea $(\mathrm{mg} / \mathrm{dI})$ & $41.31 \pm 27.6$ & $27.5(5-50)$ & 0.000 \\
\hline Creatinine $(\mathrm{mg} / \mathrm{dI})$ & $1.26 \pm 0.93$ & $1.1(0.6-1.6)$ & 0.087 \\
\hline $\mathrm{Na}(\mathrm{mg} / \mathrm{dI})$ & $141.37 \pm 11.52$ & $140(135-145)$ & 0.237 \\
\hline $\mathrm{K}(\mathrm{mg} / \mathrm{dI})$ & $4.38 \pm 3.89$ & $4.15(3.5-5)$ & 0.553 \\
\hline
\end{tabular}


Table 3: The serum urea, creatinine, $\mathrm{Na}$ and $\mathrm{K}$ in the study population according to age.

\begin{tabular}{|c|c|c|c|}
\hline Parameters & $<60$ Years $($ Mean \pm SD) & $>60$ Years $($ Mean \pm SD) & $P$-value \\
\hline Urea $(\mathrm{mg} / \mathrm{dI})$ & $42.3 \pm 27.7$ & $40.8 \pm 27.9$ & 0.804 \\
\hline Creatinine $(\mathrm{mg} / \mathrm{dI})$ & $1.3 \pm 0.8$ & $1.2 \pm 0.9$ & 0.765 \\
\hline $\mathrm{Na}(\mathrm{mg} / \mathrm{dI})$ & $141.9 \pm 12.5$ & $141.1 \pm 11.1$ & 0.717 \\
\hline $\mathrm{K}(\mathrm{mg} / \mathrm{dI})$ & $3.8 \pm 1.0$ & $4.7 \pm 3.8$ & 0.290 \\
\hline
\end{tabular}

Table 4: The correlation serum parameters in the study population

\begin{tabular}{|r|c|c|c|c|c|}
\hline \multicolumn{2}{|c|}{ Parameters } & $\begin{array}{r}\text { Urea } \\
(\mathrm{mg} / \mathrm{dI})\end{array}$ & $\begin{array}{r}\text { Creatinine } \\
(\mathrm{mg} / \mathrm{dI})\end{array}$ & Na (mg/dI) & .025 /dI) \\
\hline Urea & P-value & & $.598^{* *}$ & .063 \\
\hline & R-value & & .000 & .020 & .536 \\
\hline Creatininee & P-value & $.598^{* *}$ & & .845 & $. .037-$ \\
\hline $\mathrm{Na}$ & R-value & .000 & & & .716 \\
\hline & P-value & .025 & .020 & .002 \\
\hline $\mathrm{K}$ & R-value & .807 & .845 & .002 & .986 \\
\hline & P-value & .063 & $-.037-$ & .986 & \\
\hline
\end{tabular}

\section{Discussion}

Sudanese prostate cancer under Androgen One hundred deprivation therapy was enrolled in this study. The study carried out in Khartoum oncology hospital in Khartoum state during April and July 2018. The use of ADT in the treatment of advanced prostate cancer has been shown to delay the clinical progression of the disease. However, the testosterone suppression associated with this therapy may lead to a hypogonadal condition that can have detrimental effects on renal parameters. Our result, the (mean $\pm \mathrm{SD})$ of serum urea, creatinine, were $(41.31 \pm 27.6 \mathrm{mg} / \mathrm{dl}, \quad 1.26 \pm 0.93 \mathrm{mg} / \mathrm{dl}), \quad$ this study disagree with (Reshma et al., 2014) who is reported that, serum creatinine and urea has high than the normal range. In addition, there is preclinical evidence suggesting a protective effect of testosterone on the peripheral circulation. Specifically, testosterone appears to protect the kidney by inducing vasodilatation in the renal vessels (Molinari et al., 2002). Used ADT might antagonize testosterone, thereby increasing the risk of damage to the glomerulus. Furthermore, ADT induced hypogonadism leads to estrogen deficiency, which a play role in renal injury by reducing glomerular endothelial permeability (Hutchens et al., 2012). The $($ mean \pm SD) of serum $\mathrm{Na}$ and $\mathrm{K}$ were $(141.37 \pm 11.52 \mathrm{mg} / \mathrm{dl}, 4.38 \pm 3.89 \mathrm{mg} / \mathrm{dl})$, our results agree with (Javed et al., 2016). Water intoxication with sodium level has been assumed as the main 
cause of prostate cancer. (Norlen et al.,1990) have reported that, changes in $\mathrm{K}$ level due to diluted water was used as an irritant. The exact cause of $\mathrm{K}$ level changes is not known. It is probably due to haemolysis during the absorption of fluid into circulation. Their no publish research study was done in Sudan concerning this study. And no data available has done in this research study.

Conclusion: This study concluded that androgen deprivation therapy not effected on blood renal parameters among prostate cancer, the levels of serum creatinine, urea and electrolytes in this study were reported within the normal ranges and also our study reported that the positive correlation between serum urea and creatinine.

\section{References}

\section{Cairns P, Esteller M, Herman JG, Schoenberg}

M. Molecular detection of prostate cancer in urine by GSTP1 hypermethylation. Clin Cancer Res, 2001; 7(9):2727-30.

Braga-Basaria M, Muller DC, Carducci MA, et al. Lipoprotein profile in men with prostate cancer undergoing androgen deprivation therapy. Int J Impot Res. 2006;18(5):494-498.

Basaria S. Androgen deprivation therapy, insulin resistance, and cardiovascular mortality. J Androl. 2008;29(5):534-539.

Braga-Basaria M, Dobs AS, Muller DC, et al. Metabolic syndrome in men with prostate cancer undergoing long-term androgen-deprivation therapy. J Clin Oncol. 2006;24(24):3979-3983.

Kambham N, Markowitz GS, Valeri AM, Lin J, D'Agati VD. Obesity-related glomerulopathy: an emerging epidemic. Kidney Int. 2001;59(4): 14981509.

Molinari C, Battaglia A, Grossini E, et al. The effect of testosterone on regional blood flow in effect of testosterone on regional blood flow in prepubertal anaesthetized pigs. J Physiol. 2002;543(pt 1):365372.

Hutchens MP, Fujiyoshi T, Komers R, et al. Estrogen protects renal endothelial barrier function from ischemia-reperfusion in vitro and in vivo. Am $\mathrm{J}$ Physiol Renal Physiol. 2012;303(3):F377-F385.

Wada Y, Nakanishi J, Takahashi W, Kai N, Nakayama Y, Yamashita Y, Honda J, Ueda S. Mass screening for prostate cancer in patients with end-stage renal disease: a comparative study. BJU Int 2006; 98(4):794-797.

Reshma K, Sudha K, Poornima A Manjrekar, Madan Gopal R, Spouparnika, Yogesh K, Ravikiran A. Evaluation of biochemical markers of renal dysfunction in prostate disorder and healthy controls. IJBAR (2014) 05 (09).

Javed A, Adeel H, Bikha R, Saira B. Serum electrolytes disturbance in benign prostate hyperplasia after transurethral resection of the proatate. J Nephrol Ther 6: 238. doi:10.4172/21610959.1000238 .

Norlen H, Dimberg M, Vinnars E, Aligen LG, Brandt LG .Water and electrolytes in muscle tissue and free amino acids in muscle and plasma in connection with transurethral resection of the prostate using distilled water as an irrigating fluid. Scand J Urol Nephrol. 1990. 24: 21-26. 